\title{
Article \\ The Assessment of the Usefulness of Platelet-Rich Fibrin in the Healing Process Bone Resorption
}

\author{
Iwona Niedzielska, Daniel Ciapiński, Michał Bąk* (D) and Damian Niedzielski
}

Citation: Niedzielska, I.; Ciapiński, D.; Bak, M.; Niedzielski, D. The Assessment of the Usefulness of Platelet-Rich Fibrin in the Healing Process Bone Resorption. Coatings 2022, 12, 247. https://doi.org/ 10.3390/coatings12020247

Academic Editors: James Kit-hon Tsoi and Gabriela Graziani

Received: 23 December 2021 Accepted: 11 February 2022 Published: 14 February 2022

Publisher's Note: MDPI stays neutral with regard to jurisdictional claims in published maps and institutional affiliations.

Copyright: (C) 2022 by the authors. Licensee MDPI, Basel, Switzerland. This article is an open access article distributed under the terms and conditions of the Creative Commons Attribution (CC BY) license (https:// creativecommons.org/licenses/by/ $4.0 /)$.
Department of Cranio-Maxillo-Facial Surgery, Medical University of Silesia in Katowice, ul. Francuska 20-24, 40-027 Katowice, Poland; niedzielska.konsultant@wp.pl (I.N.); daniel.ciapinski@gmail.com (D.C.); niedzielskidamian@gmail.com (D.N.)

* Correspondence: mbak@sum.edu.pl

\begin{abstract}
The main subject of this research was the use of PRF in dental surgery aimed at preventing changes in alveolar height and width after tooth extraction. Due to the large growth factor content, it seems to be particularly useful in bone loss management starting from the simplest loss occurring after tooth extraction through loss resulting from tooth resection ending with loss caused by large bone cysts. The study was performed on 50 patients. The extraction of two maxillary or mandibular homonymous teeth was carried out in each patient, where PRF was placed in one alveolus while the other alveolus was left empty. Then, the alveoli were surgically managed with a split flap technique. On the extraction day, after 10 days, and after 6 months, the alveolar process was measured, soft tissues healing was assessed, and imaging examinations were analyzed. It was proved that the healing of soft tissues in the PRF group was better. In the PRF group after 6 months from surgery, the newly formed bone had higher grayscale values in volumetric tomography (CBCT). Moreover, the reduced atrophy of the alveolar process at the site of the extracted tooth was proved in this study.
\end{abstract}

Keywords: platelet-rich fibrin; guided bone regeneration; bone preservation; cone beam computed tomography

\section{Introduction}

At present, implantological treatment has become a popular method of tooth replacement. However, to be successful and to satisfy high white and red aesthetic standards, it requires the appropriate amount of bone and keratinized gingiva. Appropriate alveolar process management after tooth loss becomes important for minimizing the reduction of the alveolar process volume, which makes the treatment as inexpensive and non-invasive as possible. Today, atraumatic tooth extraction using periotomes is the gold standard, but it does not prevent the loss of the alveolar process volume entirely. The remodeling and healing of the post-extraction alveolus involve the reduction of width and height of the post-extraction alveolus already in the first 8 days [1,2]. This physiological bone atrophy amounts, on average, to $25 \%-30 \%$ [3] and, according to some authors, atrophy amounting to $40 \%-60 \%$ of the alveolar process volume occurs in $2-3$ years $[4,5]$. The healing of the alveolus is the outcome of the resorption process and neo-osteogenesis, which take place from the outside and the inside of the alveolus and have an impact on the shape and appearance of the alveolar process [6]. Araujo and Lindhe's research shows that the healing of the alveolus entails mainly bone atrophy from the side of the oral vestibule and that the alveolus is always below the level of adjacent teeth. Cells responsible for bone formation are, in this case, not active enough or there are too few of them [7].

The best material for bone loss regeneration is the autogenous bone obtained either from maxillary or mandibular bone as well as from outside of the oral cavity [8]. Only the autogenous bone and some allogenic materials have osteoinductive abilities. The remaining materials act osteoconductively as a thrombus stabilizer or construction for infiltrating cells $[9,10]$. 
In 2001, Joseph Choukroun et al. made an effective attempt to obtain platelet-rich fibrin (PRF) from whole blood [11]. This method is a simple and cheap procedure based on natural biological processes. One of its major advantages is avoiding the use of coagulation factors, bovine thrombin, calcium chloride, or gelling agents. Moreover, it is not harmful to the organism [12]. PRF contains numerous blood platelets as well as cytokines, which are released from the thrombus. However, the most crucial is the platelet-rich fibrin matrix, which is responsible for actual therapeutic potential [13-17]. Standalone cytokines quickly lose their activity, but they have much greater significance in combination with the fibrin matrix. The PRF matrix combined with cytokines demonstrates longer activity, unlike other fibrin glues. The research proved that living platelets contained in PRF were able to release growth factors, i.e., platelet-derived growth factor (PDGF), vascular endothelial growth factor (VEGF), and transforming growth factor (EGF) in the same concentration for 7 days $[11,18]$.

Thus, PRF has found application in dental and maxillofacial surgery, plastic surgery, otolaryngology, and chronic wound treatment [11,19-21]. Publications over the last few years concerning platelet-rich fibrin include practically all the fields of dentistry. It has been used for treating the perforation of the bottom of the pulp cavity in combination with MTA, multiple gingival recessions, or periodontal diseases [22-27].

This study aimed to answer three principal questions:

1. Can the insertion of the PRF to the post-extraction socket enhance soft tissue and bone healing?

2. How does the insertion of the PRF to the post-extraction socket affect the CBCT measured grayscale values?

3. How does the insertion of the PRF to the post-extraction socket affect the postextraction bone loss?

\section{Materials and Methods}

A randomized study was performed on a group of patients reporting to the University Hospital Outpatient Clinic of Maxillofacial Surgery in Katowice in the years 2011/2012 for the sanitation of the oral cavity. The study was approved by the bioethics committee of the Medical University of Silesia (protocol: KNW/0022/KB1/97/II/10/11).

Based on medical history, physical examination, and additional examinations (i.e., panoramic radiographs and intraoral X-rays), patients meeting the following criteria were qualified for further study.

Inclusion criteria for the study:

1. The presence of two maxillary or mandibular homonymous teeth qualified for extraction (teeth with pulp gangrene with or without periapical lesions with a diameter of no more than $1 \mathrm{~cm}$, which cannot be treated conservatively due to the fact of considerable damage to the crowns of the teeth; teeth after the failures and complications of endodontic treatment with considerable damage to the tooth crown);

2. The bony walls of the alveolus are intact during extraction and the adjacent teeth are preserved;

3. The extraction of two teeth in the same patient comparable concerning surgical procedure in duration;

4. The lack of local and general contraindications for tooth extraction;

5. Patients without systemic diseases.

Patients with metabolic diseases, active smokers, chronic alcoholics as well as patients after radiotherapy and chemotherapy within the head and neck area and patients with chronic periodontal disease were excluded from the study.

\subsection{Surgical Procedure}

The minimally invasive extractions of two homonymous teeth were carried out under local anesthesia with $2 \%$ lidocaine with noradrenaline. After performing anesthesia, venous blood was collected from the cubital fossa in the amount of $18 \mathrm{~mL}$ for the incisors, canines, 
and premolars' alveoli as well as $27 \mathrm{~mL}$ for the molars' alveoli. The blood was collected in $9 \mathrm{~mL}$ vacuum test tubes and centrifuged using the EBA-20 centrifuge at $2700 \mathrm{rpm}$ in accordance with the protocol described in 2001 by Joseph Choukroun.

The lack of anticoagulants allowed for the activation of the majority of platelets and triggered the coagulation cascade in a simple manner. The whole process of slow coagulation and centrifugation resulted in the formation of the fibrin clot containing platelets located in the middle part of the test tube. Platelet-rich fibrin was located between the mass of red blood cells, red base corpuscles (RBCs) at the bottom, and platelet-poor plasma (PPP) at the top [20,28] (Figure 1).

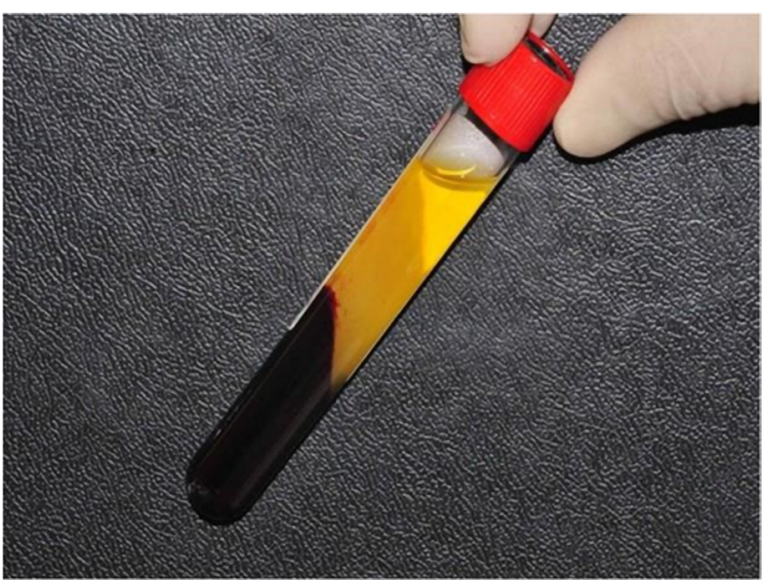

Figure 1. Vacuum tube after centrifugation (3 layers visible- the middle is the PRF).

After centrifuging, the PRF clot was removed from the test tube (Figure 2a) and separated from red blood cells (Figure $2 b$ ) in such a form that it was inserted into one of the alveoli after homonymous teeth extraction. The study was performed according to the outline included in Table 1.

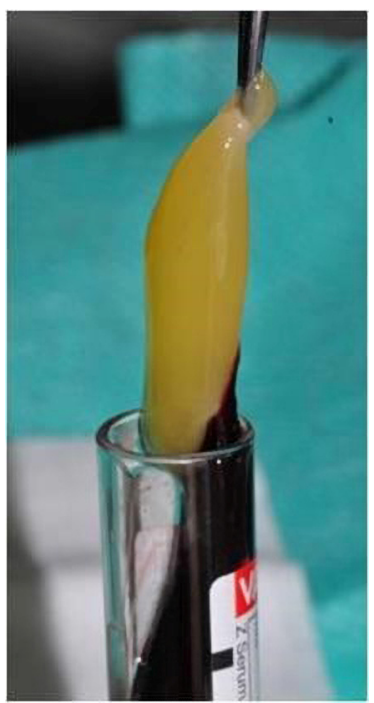

(a)

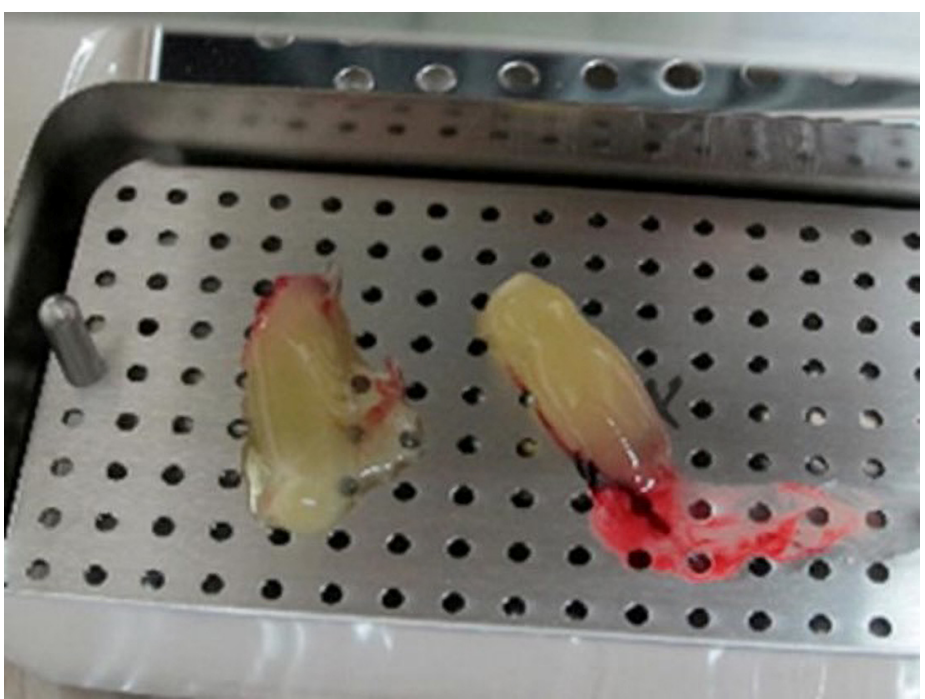

(b)

Figure 2. Centrifuged PRF: (a) removing the PRF from the test tube; (b) PRF separated from red blood cells. 
Table 1. Study outline.

\begin{tabular}{|c|c|c|}
\hline Teeth Extraction Day & 10th Day after the Extraction & 6 Months after Extraction \\
\hline $\begin{array}{l}\text { alveolar width and } \\
\text { height measurement } \\
\text { with Koehler } 6401 \\
\text { caliper }\end{array}$ & $\begin{array}{ll}\text { - } & \text { ARSTH scoring } \\
\text { - } & \text { CBCT and alveolus } \\
& \text { measurements }\end{array}$ & 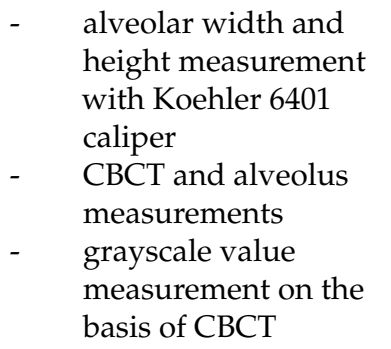 \\
\hline
\end{tabular}

After extracting the teeth, the presence of the bony walls of the alveoli was checked by means of the 3182 Kohler periodontal probe. With the aid of the same periodontal and the 6401 Kohler compass, the width and height of the alveolar process were measured. The measurement of the width of the alveolar process was carried out in the transverse dimension using the Kohler compass at intervals of $3 \mathrm{~mm}$ counting from the rim of the lowest alveolar lamella (assessed using the 3182 Kohler periodontal probe) to the maximum height of $12 \mathrm{~mm}$ (Figure 3).

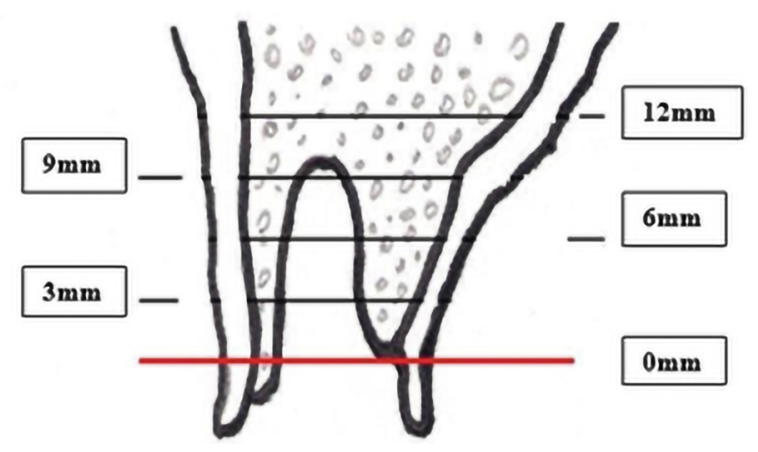

Figure 3. Alveolar transverse width measurement.

The height of the alveolar process was measured with the periodontal probe. The auxiliary reference line-the IC line drawn through the top of the buccal cusps of the teeth adjacent to the post-extraction socket was defined for that purpose. The measurement was performed in the midline of the alveolus, and the distance between the IC line and the vestibular alveolar bone was measured. The obtained value was recorded as the HIC distance (Figure 4).

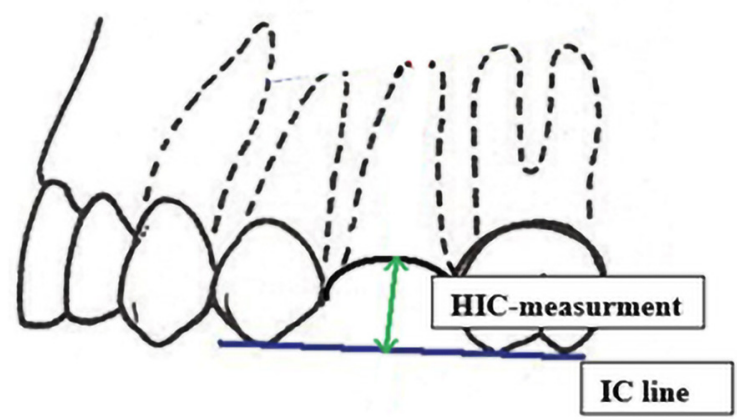

Figure 4. HIC distance measurement. 
After measuring the width and the height of the alveolar process of one of the postextraction alveoli, platelet-rich fibrin was inserted so that it filled the alveolus tightly (the study group-Group I). Next, the mucosal flap for covering the alveolus was split with the use of a scalpel with blade number $15 \mathrm{c}$.

In the case of maxillary alveoli, a rotated palatal flap was used, whereas in the case of mandibular alveoli, a mucosal flap from the oral vestibule was applied. The flaps were prepared in such a way that it was possible to close the wound without tightening the soft tissues. Next, tight surgical wound closure was performed using $6 / 0$ nylon stitches.

The other homonymous alveolus (the control group-Group II) was surgically managed in an analogical manner as on the other side of the dental arch with the difference that PRF was not inserted in the alveolus. After performing measurements, a rotated palatal flap was prepared in the case of maxillary teeth and a mucosal flap from the oral vestibule in the case of the mandible. Tight surgical wound closure was performed using 6/0 nylon stitches.

\subsection{Postoperative Care}

Patients were not prescribed any antibiotics in the postoperative period. Brushing the teeth with a soft brush at least twice a day excluding the surgical field for the period of 10 days, that is, till the day of stitches removal, was recommended. Over the first postoperative days, that is, up to 10 days, abstaining from food of hard consistency was recommended.

After 10 days from the surgery, the stitches were removed, and the course of the alveoli healing was clinically assessed. The notion of the Assessment Rate of Soft Tissues Healing (ARSTH) was created according to the authors' ideas and for this study. ARSTH is based on a five-grade scale including the assessment of five factors:

1. The appearance of the wound: infected-0 points, clean -1 point;

2. Oedema: present -0 points, not present -1 point;

3. Discharge from the wound: present -0 points, not present -1 point;

4. The tightness of wound closure: wound dehiscence- -0 points, tight wound closure1 point;

5. Pain reported by the patient on the VAS scale: 5 or more- 0 points, less than $5-$ 1 point.

The patients received maximally 5 points if the wound was clean, without oedema, without discharge, was tight, and the pain was assessed by the patient as less intense than 5 on the VAS scale (Visual Analogue Scale).

Simultaneously, after 10 days from the surgery, the patient was subjected to CBCT (cone beam computed tomography) examination, limited to the area of the post-extraction alveoli using the Kodak 9000 apparatus (Figure 5), and the alveolus width and height were measured. 


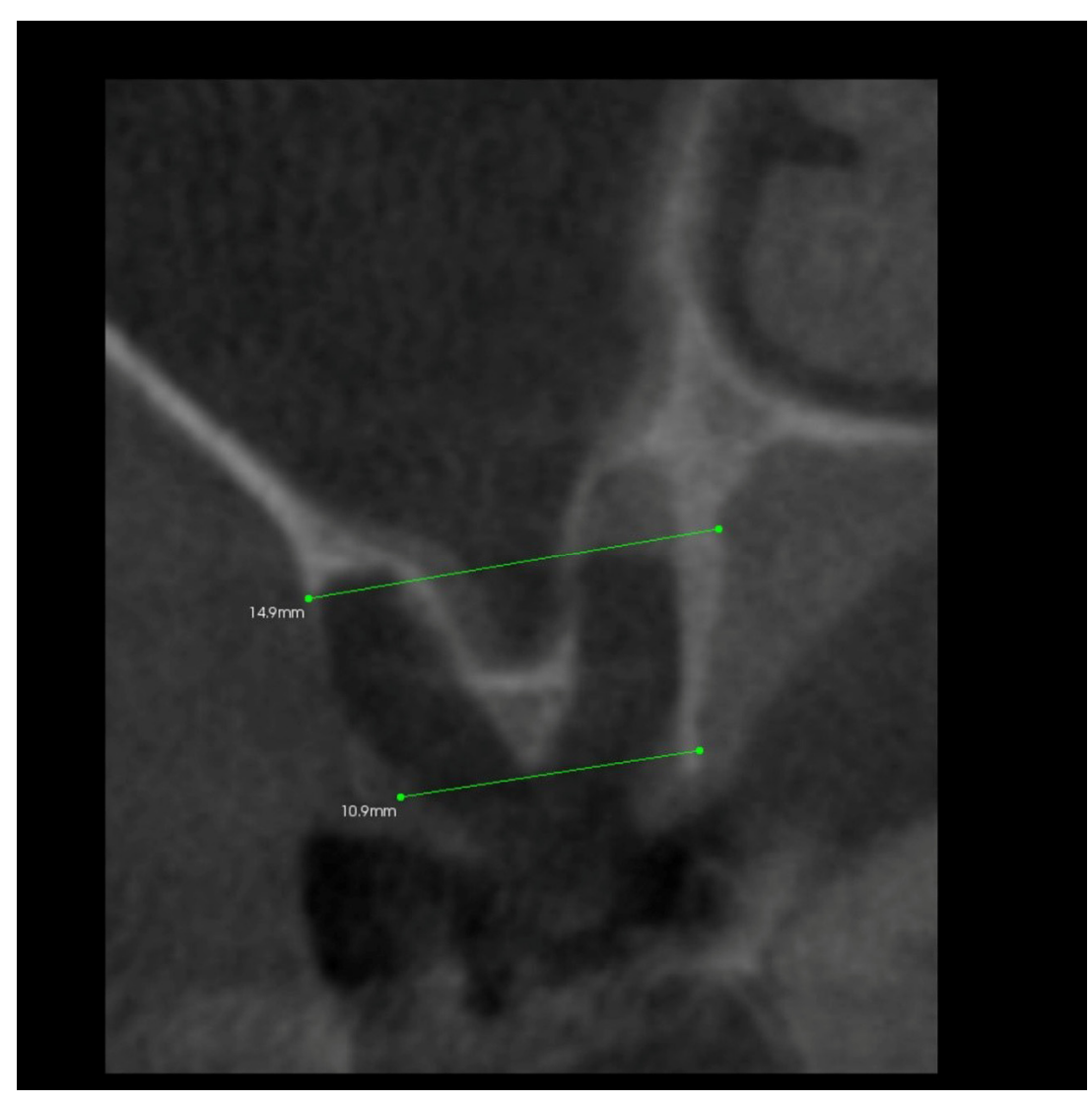

Figure 5. Transverse imaging of maxillary alveolus obtained from CBCT. The alveolus width measurement 10 days post-extraction.

After 6 months, the measurements of the alveolar process width and height were repeated. The examination was analogical as on the day of tooth extraction.

In addition, 6 months after the surgery, another performance of volumetric CBCT limited to the area of the post-extraction alveoli using the Kodak 9000 apparatus was recommended. During these examinations, the alveolar process in the extraction site and grayscale values in the selected measurement points were measured (Figures 6-9).

After 6 months from tooth extraction, grayscale values were assessed. To define the points of measurement, the auxiliary reference lines were defined:

1. The A line drawn through the apexes of the teeth adjacent to the post-extraction socket;

2. The IC line drawn through the top of the buccal cusps of the teeth adjacent to the pos-extraction socket;

3. The midline of the post-extraction socket (alveolus).

Then, the two points of grayscale values were defined (Figure 8):

Point (A) 1/3 of the distance between the A line and the IC line following the midline; Point (B) At the intersection of the midline and the A line. 


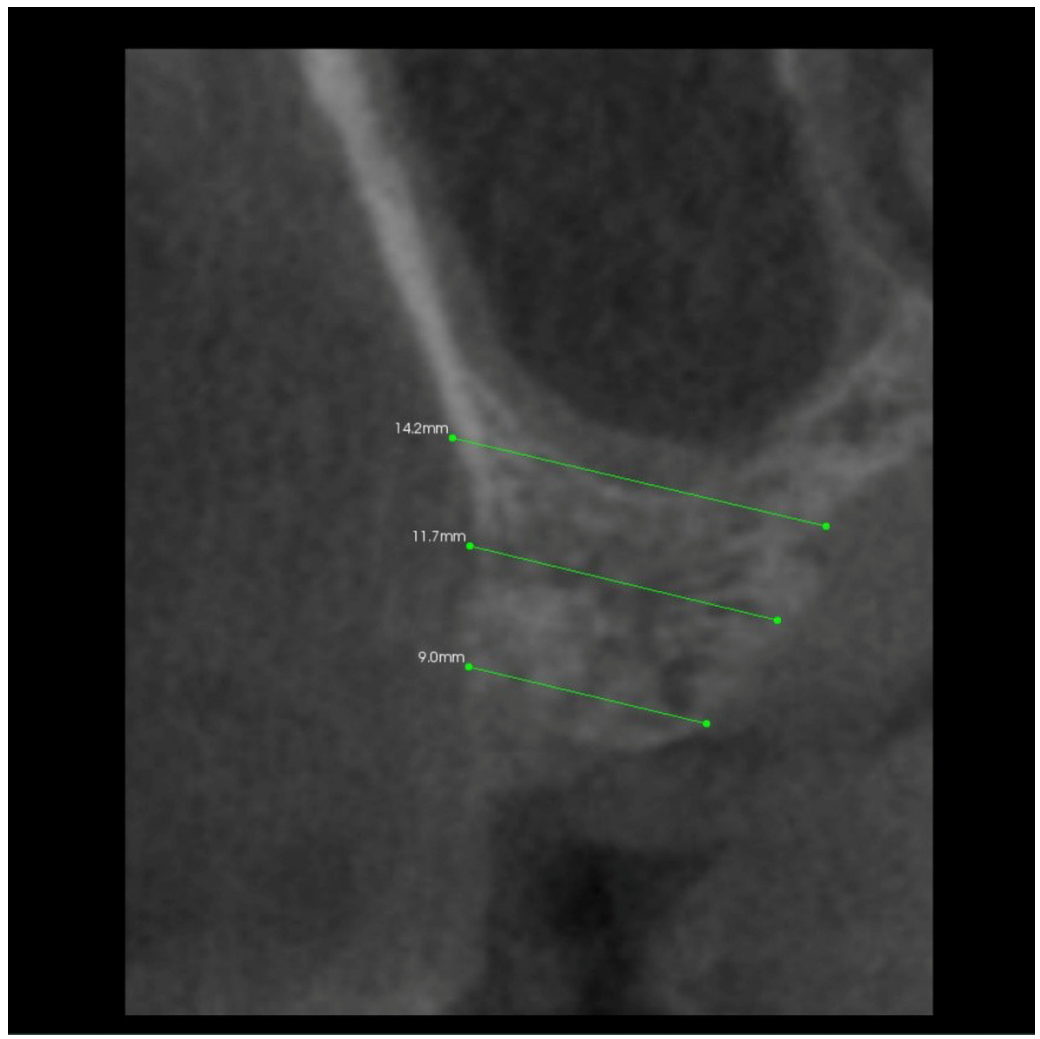

Figure 6. Transverse imaging of maxillary alveolus in CBCT. Alveolar width measurement 6 months post-extraction.

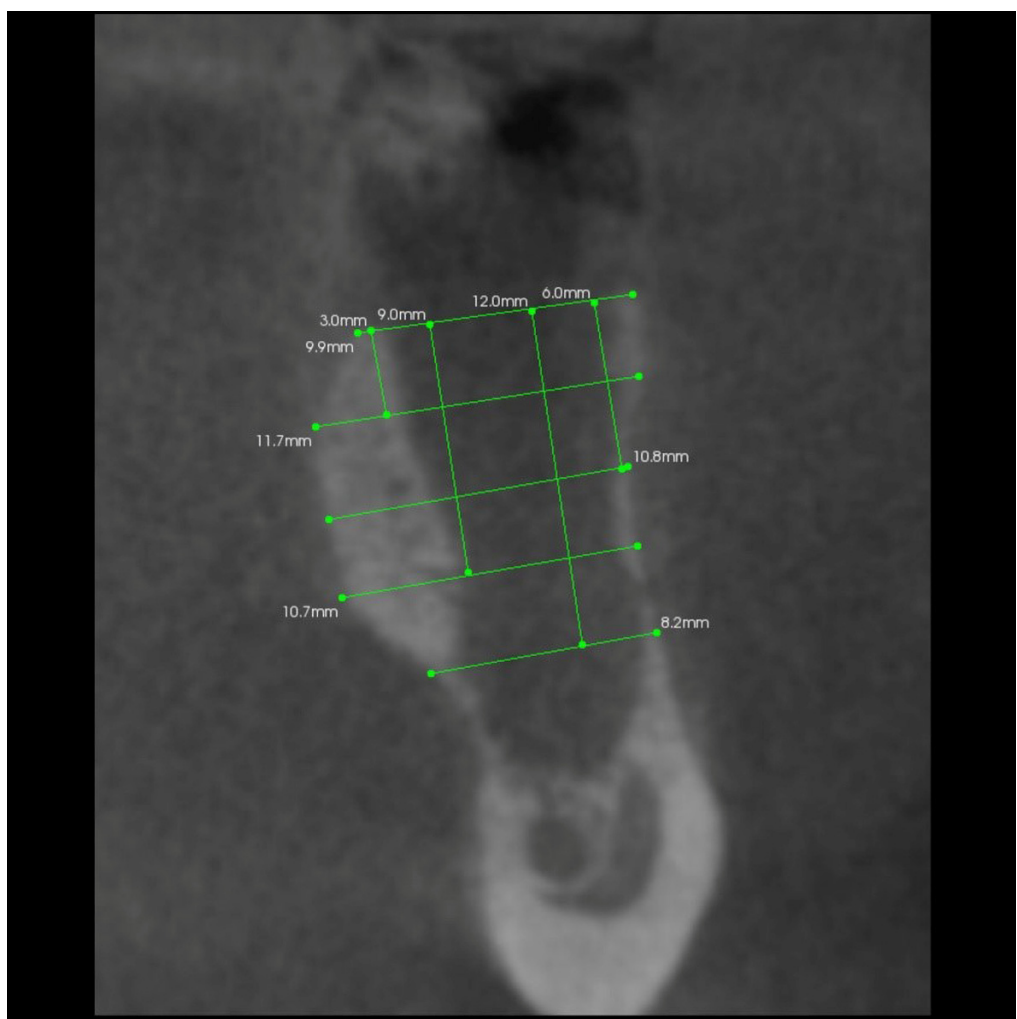

Figure 7. Transverse imaging of mandibular alveolus obtained from CBCT. The alveolus width measurement 10 days post-extraction. 


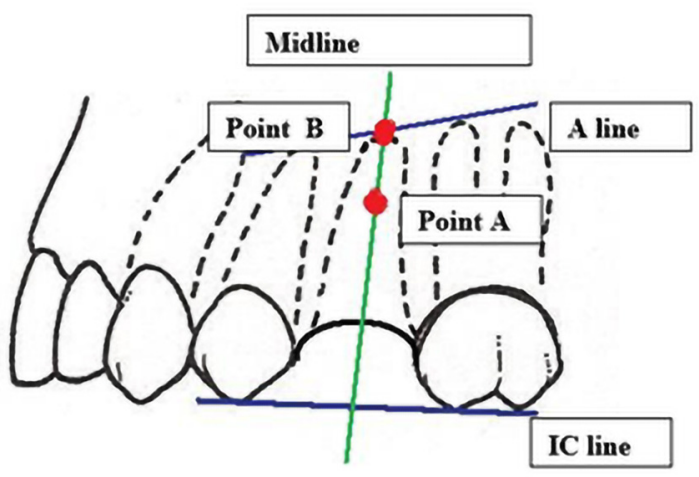

Figure 8. Grayscale value measurement points.

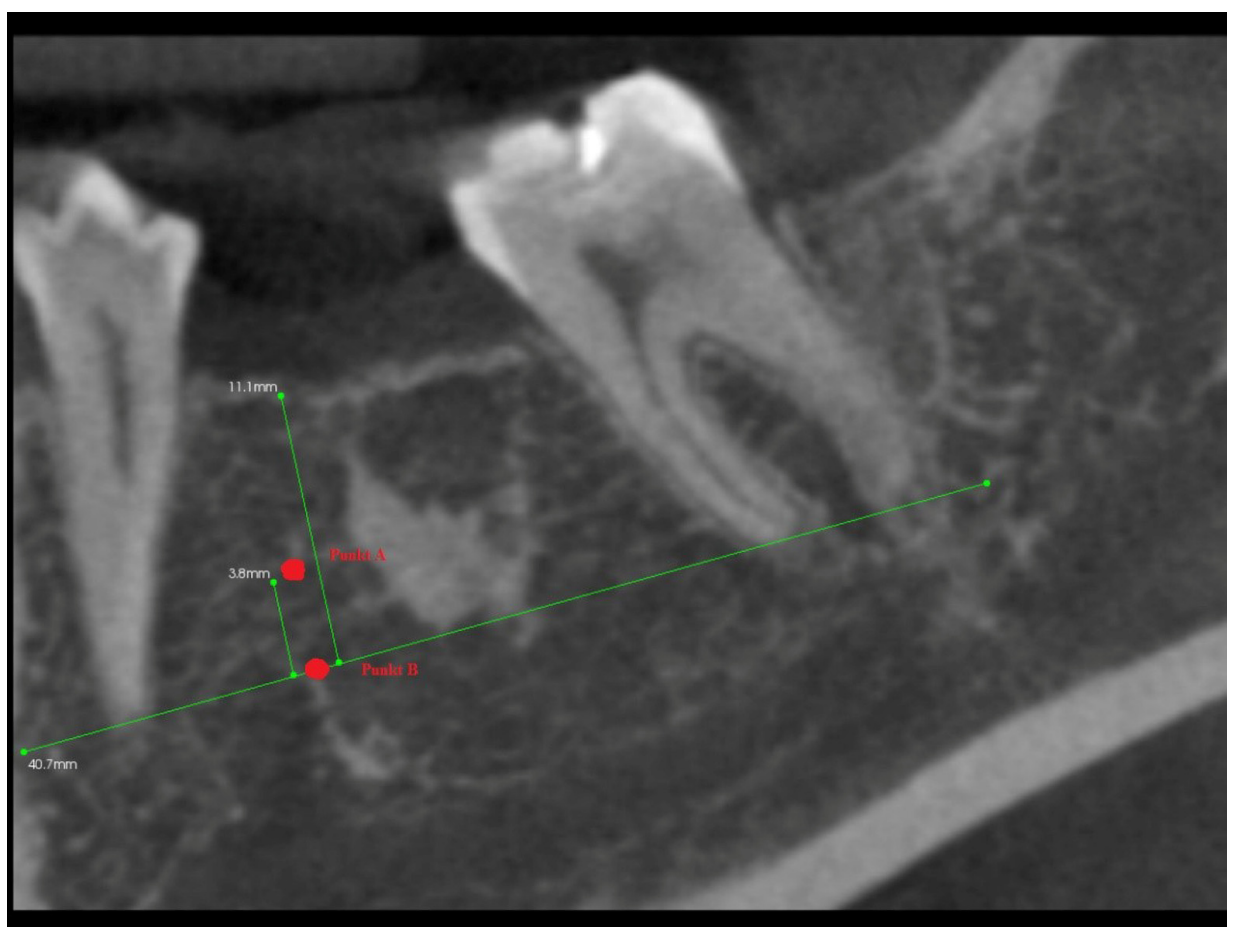

Figure 9. Longitudinal imaging of mandibular alveolus in CBCT. Grayscale value measurement 6 months post-extraction.

\section{Results}

An analysis of the results was carried out using the PQStat ver.1.4.2.324 statistical package.

The study was conducted on a group of 50 patients including 22 women and 28 men aged from 18 to 59 (Figure 10). The mean age in the study group was 35.68. One hundred tooth extractions were performed in the patients. Molars were the most frequently extracted teeth $(54 \%)$, more often upper than lower; next were premolars $(18 \%)$, canines $(6 \%)$, and incisors (2\%). Teeth with gangrenous pulp with considerable damage to the tooth crown (48 teeth) and improperly treated root canals (36) were most frequently extracted. Teeth with complications after improper treatment (16 teeth-including breaking instruments for root canal treatment, perforation of the bottom of the pulp cavity, and perforation of the roots) required surgical intervention less frequently. 


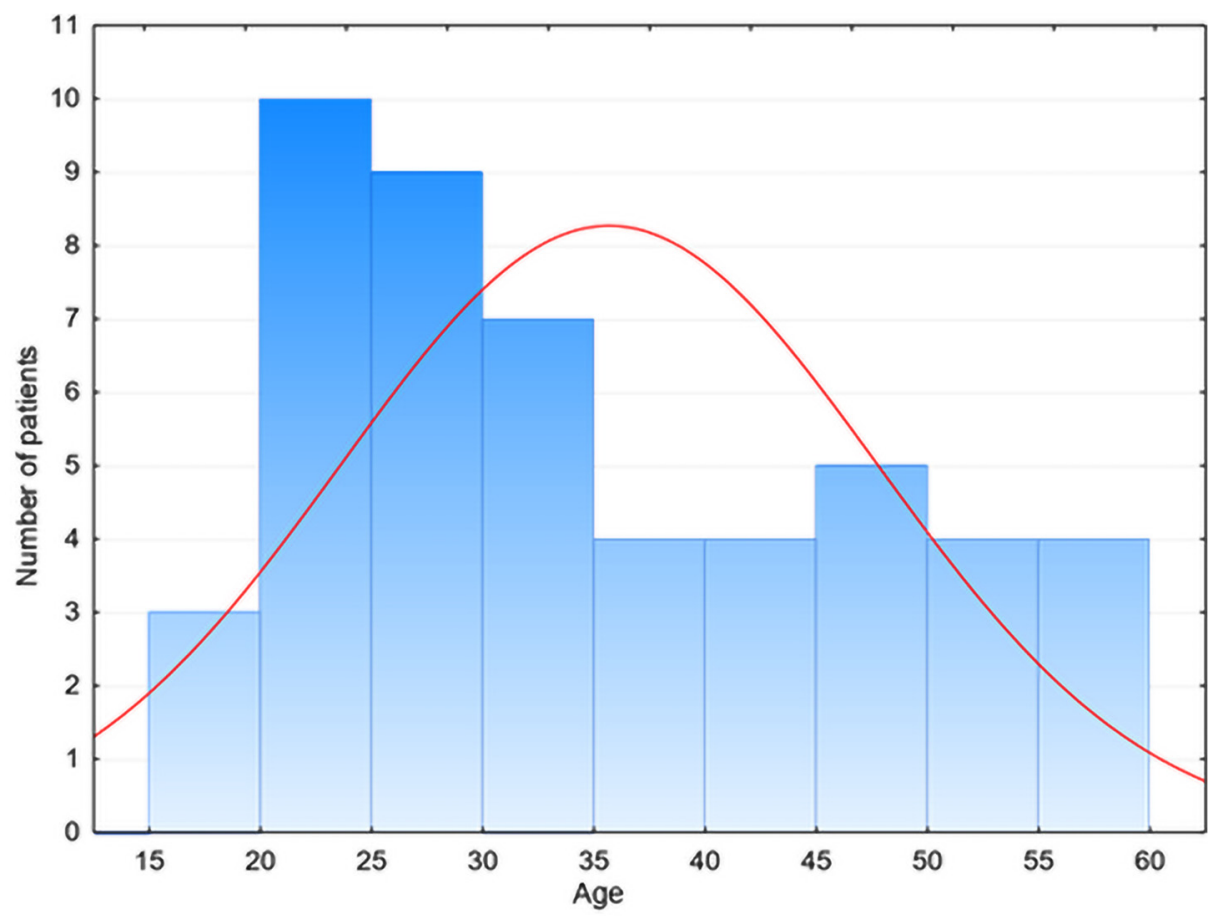

Figure 10. Age distribution in the research group.

3.1. The Assessment of Soft Tissues Healing (ARSTH) for the Alveolar Area (with and without PRF Insertion) Assessed after 10 Days from Tooth Extraction

After 10 days from tooth extraction, more frequent wound infections were observed in the cases of extractions of teeth in which PRF was not inserted in the alveolus $(p=0.0233)$ (Table 2). Oedema, assessed also on day 10, occurred more frequently in the alveolar area without PRF compared to the side where platelet-rich fibrin was applied, but this difference was of little statistical significance. Pain occurred in Group II, the control group where platelet-rich fibrin was not used, much more frequently in comparison to the study group where PRF was used ( $p=0.0265$ ) (Table 2). Wound healing complications in the form of wound dehiscence were found in isolated cases in both groups, but all of them were not statistically significant (Table 2). Therefore, the positive influence of platelet-rich fibrin employment on the process of wound healing can be observed.

Table 2. Soft tissue healing assessment in the group of 50 patients performed on the 10th day post-extraction according to the ARSTH scoring scale.

\begin{tabular}{|c|c|c|c|c|c|}
\hline \multirow[b]{2}{*}{ Factor } & \multicolumn{2}{|c|}{ Group I* } & \multicolumn{2}{|c|}{ Group II * } & \multirow{2}{*}{ McNemar Test } \\
\hline & Number & $\%$ & Number & $\%$ & \\
\hline Clean wound & 48 & 96.0 & 41 & 82.0 & \multirow{2}{*}{ Chi2 $=5.14, p=0.0233$} \\
\hline Infected wound & 2 & 4.0 & 9 & 18.0 & \\
\hline No swelling & 37 & 74.0 & 32 & 64.0 & \multirow{2}{*}{ Chi2 $=2.29, p=0.1306$} \\
\hline Swelling & 13 & 26.0 & 18 & 36.0 & \\
\hline No discharge & 48 & 96.0 & 41 & 82.0 & \multirow{2}{*}{ Chi $2=5.14, p=0.0233$} \\
\hline Discharge & 2 & 4.0 & 9 & 18.0 & \\
\hline VAS pain $<5$ & 38 & 76.0 & 29 & 58.0 & \multirow{2}{*}{ Chi $2=4.92, p=0.0265$} \\
\hline VAS pain $>5$ & 12 & 24.0 & 21 & 42.0 & \\
\hline Tight wound & 48 & 96.0 & 44 & 88.0 & \multirow{2}{*}{ Chi $2=1.50, p=0.2207$} \\
\hline Wound dehiscence & 2 & 4.0 & 6 & 12.0 & \\
\hline
\end{tabular}

* Group I—alveoli with PRF; Group II—alveoli without PRF. 
3.2. The Results of Mean Values of the Alveolar Process Width and Height Measurements Performed after Tooth Extraction within the Space of 6 Months for Two Different Alveoli in the Same Patient

No statistically significant differences of mean values of the alveolar process width and height (HIC distance) measurements performed directly after tooth extraction were found for the alveoli in which platelet-rich fibrin was not used in comparison to the alveoli where platelet-rich fibrin was applied (Table 3). After 6 months, significant differences concerned primarily the mean values of the alveolar process width and height measurements $(p=0.0085)$. Larger values were observed in Group I where PRF was used. In the PRF group, mean width measurement amounted to $9.43 \pm 1.74 \mathrm{~mm}$, whereas in the group without PRF, it amounted to $9.15 \pm 1.51 \mathrm{~mm}$ (Table 3). Within the space of 6 months, changes in the mean values of the measurements of the alveoli width were significant $(p=0.0016)$ (Table 3). In the platelet-rich fibrin group, the average loss of the alveolar process amounted to $1.49 \pm 0.84 \mathrm{~mm}$, whereas in the non-PRF group, it amounted to $1.85 \pm 0.86 \mathrm{~mm}$ (Table 3 ).

Table 3. The mean values of alveolar width and height in Group I (PRF) and Group II (no PRF) measured 10 days and 6 months post-extraction and the change of values in time.

\section{Descriptive Statistics}

\begin{tabular}{|c|c|c|c|c|c|c|c|c|c|c|}
\hline Variable & $\begin{array}{l}\text { Time Post- } \\
\text { Extraction }\end{array}$ & 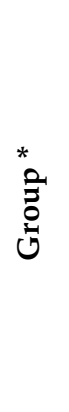 & $\sum_{\Sigma}^{\Xi}$ & 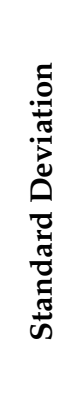 & 志 & 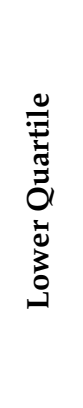 & $\frac{\Xi}{\stackrel{\Xi}{\Xi}}$ & 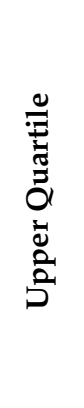 & 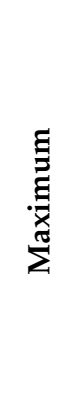 & 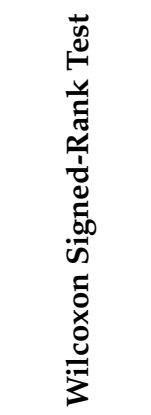 \\
\hline \multirow{4}{*}{ Alveolar width } & \multirow{2}{*}{0 days } & $\mathrm{I}$ & 10.92 & 2.15 & 7.0 & 9.0 & 11.3 & 13.0 & 14.5 & $Z=0.83$ \\
\hline & & II & 11.01 & 1.95 & 7.0 & 10.0 & 11.0 & 12.0 & 14.0 & $p=0.4043$ \\
\hline & \multirow{2}{*}{6 months } & I & 9.43 & 1.74 & 5.5 & 8.0 & 9.8 & 11.0 & 12.5 & $Z=2.63$ \\
\hline & & II & 9.16 & 1.51 & 6.0 & 8.0 & 9.5 & 10.0 & 12.0 & $p=0.0085$ \\
\hline \multirow{4}{*}{ HIC } & \multirow{2}{*}{0 days } & I & 9.05 & 1.27 & 7.0 & 8.5 & 9.0 & 10.0 & 12.0 & $Z=0.47$ \\
\hline & & II & 9.01 & 1.21 & 7.0 & 8.0 & 9.0 & 10.0 & 12.0 & $p=0.6402$ \\
\hline & \multirow{2}{*}{6 months } & I & 10.84 & 1.19 & 9.0 & 10.0 & 11.0 & 11.5 & 13.0 & $Z=1.17$ \\
\hline & & II & 11.01 & 1.26 & 8.5 & 10.0 & 11.0 & 12.0 & 14.5 & $p=0.2418$ \\
\hline \multirow{2}{*}{$\begin{array}{l}\text { Width change } \\
\text { (bone loss) }\end{array}$} & \multirow{2}{*}{-} & $\mathrm{I}$ & 1.49 & 0.84 & 0.5 & 1.0 & 1.5 & 2.0 & 4.5 & $Z=3.16$ \\
\hline & & II & 1.85 & 0.86 & 0.0 & 1.5 & 2.0 & 2.5 & 4.5 & $p=0.0016$ \\
\hline \multirow{2}{*}{$\begin{array}{l}\text { Height change } \\
\text { (bone loss) }\end{array}$} & \multirow[b]{2}{*}{-} & I & 1.79 & 0.61 & 0.5 & 1.5 & 1.5 & 2.0 & 3.0 & $Z=2.03$ \\
\hline & & II & 1.98 & 0.76 & 0.5 & 1.5 & 2.0 & 2.5 & 4.5 & $p=0.0426$ \\
\hline
\end{tabular}

* Group I—alveoli with PRF; Group II—alveoli without PRF. 
3.3. The Results of Mean Values of Grayscale Value Measurements for Two Alveoli (with/without PRF Insertion) after 6 Months

The highly significant differences in the distribution of grayscale values were found in the volumetric tomography in point A (in 1/3 of the section from the side of the alveolar apex) between Group I, that is the alveoli in which platelet-rich fibrin was used, and Group II, that is the control group in which platelet-rich fibrin was not inserted in the alveolus $(p=0.0097)$. The higher results of this measurement concerned Group I and amounted to $308.16 \pm 128.51$, whereas in the non-PRF group, they amounted to $279.4 \pm 136.23$ (Table 4).

Table 4. Mean values of GVs in CBCT.

Descriptive Statistics

\begin{tabular}{|c|c|c|c|c|c|c|c|c|c|}
\hline Variable & 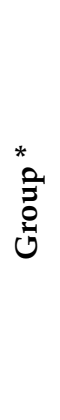 & 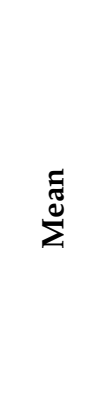 & 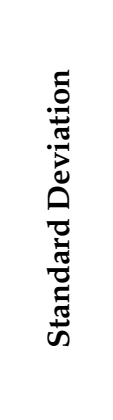 & $\underset{\Xi}{\Xi \Xi \Xi}$ & 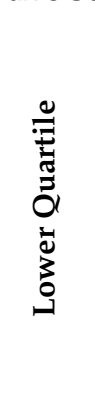 & 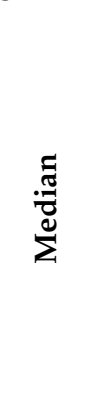 & 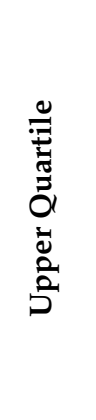 & 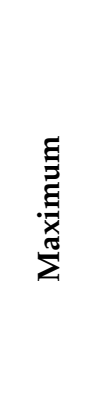 & 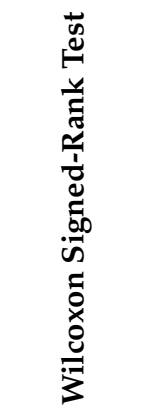 \\
\hline \multirow{2}{*}{$\begin{array}{c}\text { GV } \\
\text { (point A) }\end{array}$} & I & 308.16 & 128.15 & 55.0 & 226.0 & 282.5 & 441.0 & 557.0 & $Z=2.59$ \\
\hline & II & 279.40 & 136.23 & 75.0 & 162.0 & 256.0 & 390.0 & 576.0 & $p=0.0097$ \\
\hline \multirow{2}{*}{$\begin{array}{c}\text { GV } \\
\text { (point B) }\end{array}$} & I & 331.10 & 131.22 & 98.0 & 250.0 & 301.5 & 473.0 & 636.0 & $Z=2.59$ \\
\hline & II & 305.54 & 139.12 & 87.0 & 187.0 & 289.0 & 428.0 & 623.0 & $p=0.0097$ \\
\hline
\end{tabular}

* Group I-alveoli with PRF; Group II—alveoli without PRF.

The highly significant differences in the distribution of grayscale values were also found in the volumetric tomography in point B (at the intersection of the midline of the alveolus and the line drawn through the adjacent teeth apexes) and, again, the higher results of this measurement concerned Group I, that is the alveoli where platelet-rich fibrin was used, and amounted to $333.1 \pm 131.22$, whereas in the non-PRF group, it was $305.54 \pm 139.12$ (Table 4).

3.4. The Results of Mean Measurements of Height and Width of the Alveolar Processes of Two Extraction Sites (with and without PRF) in the Same Patient after 6 Months from Tooth Extraction Based on the Analysis of Volumetric Tomography

A statistically significant $(p=0.0148)$ change in the six months of observation was found concerning the mean values of measurements of the height of the alveolar process with larger bone atrophy for the alveoli in which PRF was not inserted. The atrophy in Group I with PRF amounted to $1.59 \pm 0.49 \mathrm{~mm}$, whereas in Group II without PRF, it amounted to $1.85 \pm 0.75 \mathrm{~mm}$ (Table 5$)$. In addition, a statistically significant $(p=0.0479)$ change in the values of measurements of the width of the alveolar process performed using CBCT was observed. In Group I with PRF, this change amounted to $0.87 \pm 0.4 \mathrm{~mm}$ and in the non-PRF group, it was $1.18 \pm 1.1 \mathrm{~mm}$ (Table 5). 
Table 5. Mean alveolar width and height 10 days and 6 months post-extraction (with and without PRF) and changes observed in CBCT examination.

\begin{tabular}{|c|c|c|c|c|c|c|c|c|c|c|}
\hline \multirow[b]{2}{*}{ Variable } & \multirow[b]{2}{*}{$\begin{array}{l}\text { Time Post- } \\
\text { Extraction }\end{array}$} & \multirow[b]{2}{*}{ Oّ' } & \multirow[b]{2}{*}{$\sum_{\Sigma}^{\Xi}$} & \multicolumn{6}{|c|}{ Descriptive Statistics } & \multirow[b]{2}{*}{ 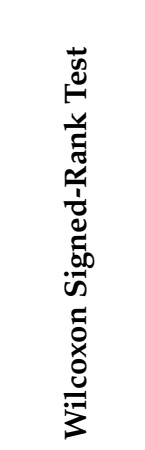 } \\
\hline & & & & 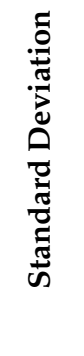 & 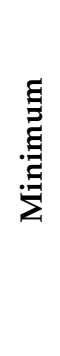 & 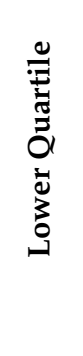 & 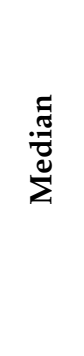 & 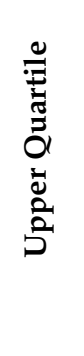 & 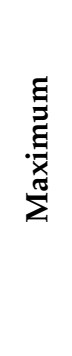 & \\
\hline \multirow{4}{*}{ Alveolar width } & \multirow{2}{*}{0 days } & I & 12.53 & 2.51 & 8.0 & 10.5 & 12.0 & 14.5 & 17.5 & $Z=1.49$ \\
\hline & & II & 12.70 & 2.32 & 8.5 & 11.0 & 12.0 & 15.0 & 18.0 & $p=0.1357$ \\
\hline & \multirow{2}{*}{6 months } & I & 11.66 & 2.34 & 7.0 & 10.0 & 11.5 & 13.0 & 16.0 & $Z=0.51$ \\
\hline & & II & 11.52 & 1.96 & 8.0 & 10.0 & 11.0 & 13.0 & 16.0 & $p=0.6105$ \\
\hline \multirow{4}{*}{ Alveolar height } & \multirow{2}{*}{0 days } & I & 9.70 & 1.95 & 6.0 & 8.0 & 9.5 & 11.0 & 14.0 & $Z=0.72$ \\
\hline & & II & 9.71 & 1.87 & 6.0 & 8.0 & 9.5 & 11.0 & 14.0 & $p=0.4692$ \\
\hline & \multirow{2}{*}{6 months } & I & 8.09 & 1.91 & 4.5 & 7.0 & 8.0 & 9.5 & 12.5 & $Z=1.07$ \\
\hline & & II & 7.96 & 2.00 & 4.0 & 6.5 & 7.8 & 10.0 & 12.0 & $p=0.2854$ \\
\hline \multirow{2}{*}{$\begin{array}{l}\text { Width change } \\
\text { (bone loss) }\end{array}$} & \multirow{2}{*}{-} & $\mathrm{I}$ & 0.87 & 0.60 & 0.0 & 0.5 & 1.0 & 1.0 & 3.0 & $Z=1.78$ \\
\hline & & II & 1.18 & 1.10 & 0.0 & 0.5 & 1.0 & 2.0 & 4.0 & $p=0.0749$ \\
\hline \multirow{2}{*}{$\begin{array}{l}\text { Height change } \\
\text { (bone loss) }\end{array}$} & \multirow[t]{2}{*}{ - } & $\mathrm{I}$ & 1.59 & 0.49 & 0.5 & 1.0 & 1.5 & 2.0 & 2.5 & $Z=2.44$ \\
\hline & & II & 1.85 & 0.75 & 0.0 & 1.5 & 2.0 & 2.0 & 4.0 & $p=0.0148$ \\
\hline
\end{tabular}

* Group I—alveoli with PRF; Group II—alveoli without PRF.

\section{Discussion}

For a long time, many authors have been looking for an ideal way to prevent bone atrophy of the alveolar process after tooth extraction. Hope is pinned on both ideal bone graft substitutes and various surgical techniques. Nevertheless, in light of the contemporary literature, this atrophy reaches values of $40-60 \%$ of the volume $[29,30]$. The preservation of the initial width and height of the alveolar process provides the foundation for later implantation or aesthetic prosthetic works [31,32].

According to Sclar et al., the preservation of the periosteum, without damaging it, while preparing the flap minimizes the loss of the buccal bone lamella [33]. Split flap preparation aimed at covering the alveoli may have a significant influence on alveolar vascularization and, thus, on the preservation of living osteoblasts and their stimulation for bone regeneration. In this study, only platelet-rich fibrin was used for filling of the alveolus. PRF was covered with a flap from the side of the oral cavity proper to avoid incisions from the side of the oral vestibule involving damage to the periosteum and the disturbance of the bone healing process through accelerating bone resorption. Covering platelet-rich fibrin (PRF) was aimed at its protection against falling out from the postextraction alveolus or dissolving. PRF is an autologous and biocompatible material that does not contain any additives. It is cheap and easy to prepare. While performing everyday surgical procedures, it does not take longer than a few additional minutes to collect and centrifuge full venous blood.

The purpose of this study was to compare the influence of the PRF application on the healing of the alveolus. The alveoli of two homonymous teeth in the same patient in the presence of the teeth adjacent to the post-extraction alveolus were compared. Many authors who concentrate their research on the prevention of the alveolar process atrophy compare random alveoli $[1,4,29,30,34,35]$. Provided the patients underwent two homonymous, mandibular, or maxillary teeth extractions, the study groups were selected most comparably. 
Moreover, patients burdened with systemic diseases as well as patients with addictions were excluded from the study to prevent the disturbance of the bone healing process.

In this study, alveoli healing was observed on the tenth day after surgery. The authors of numerous studies assess the healing process 14 days after the surgery $[4,29,31,34]$. However, if the assessment of soft tissues healing is too late, it may have a significant influence on the study's results; since with time, the total healing of tissues in both groups occurs, which was mentioned by Lauren et al. in their publication [35].

The last follow-up examination was performed after 6 months. The majority of authors assess the width and height of the bone in their reports after 6 months when it is thought that the initial period of bone healing and mineralization came to an end $[1,35]$. However, the assessment of the bone should be performed after its good mineralization, because in the case of poor mineralization it will not be visible in radiological examinations; thus, the assessment of the density and structure of the newly formed bone will be distorted $[36,37]$. For the assessment of the width and height of the alveolar process, CBCT was used. In the assessment of newly formed bone, GVs were used.

The study was conducted at the end of 2011 and the beginning of 2012 on a group of 50 patients aged from 18 to 59. In the assessment of soft tissues healing, the authors' assessment rate of soft tissues healing (ARSTH) created for this study was employed. The rate was based on the five-grade scale of the assessment of post-extraction wound healing. The statistical analysis of ARSTH on day 10 after surgery revealed a highly statistically significant difference in results in the study group and the control group. It was demonstrated that healing in the PRF group proceeds faster and with a smaller number of reported complications. The obtained results show that the employment of PRF prevents infections. In the PRF group, wound infections occurred less frequently ( $4 \%$ in Group I (where PRF was used) and 18\% in Group II). In addition, wound discharge occurred less frequently, namely, $4 \%$ in Group I and as many as $18 \%$ of cases in Group II. Moreover, a statistically significant difference in the assessment of pain on day 10 after tooth extraction was demonstrated. Pain occurred in $24 \%$ of the cases in Group I (with PRF), whereas in Group II, pain occurred in $42 \%$ of the cases. These results confirm that PRF may have an anti-inflammatory effect and prevent infections. This coincides with the expectations for this material. Dohan Ehrenfest, who is the author of numerous publications on PRF, proved the high concentration of not only platelets but also leucocytes in a PRF clot obtained according to Choukroun's protocol [38,39]. Anti-inflammatory properties and a regulating effect on the immune response were revealed $[13,40]$. Leukocytes are also responsible for the production of large amounts of VEGF [41]. The additional advantage of using this biomaterial as a separate means of preventing the atrophy of the alveolar process is a faster and less complicated surgery that does not expose the patient to the risk of complications, such as infection, and in the case of using collagen membranes also the increased risk of wound dehiscence [42].

In the conducted study, the measurements of the width and height of the alveolar process were performed directly after tooth extraction, and follow-up examinations were carried out after 6 months, that is after alveolar bone healing and remodeling. Statistically significant differences in horizontal dimensions were found. In the PRF group, the average loss of the alveolar process amounted to $1.49 \pm 0.84 \mathrm{~mm}$, and in the non-PRF group it was $1.85 \pm 0.86 \mathrm{~mm}$ (Table 3). The employment of PRF causes the growth factors contained in it to stimulate cells to differentiate faster and to produce new bone, which leads to the decreased atrophy of the alveolar bone in the transverse dimension. In in vitro studies from 2010, Dohan Ehrenfest et al. [43] proved that the release of growth factors from platelet-rich fibrin is a long-lasting process. It lasts even up to 14 days and has a stimulating effect on all cell types. They proved the release of the five most important growth factors. The concentration of these factors remained at the same level for the first few days and only then did it start to decrease. Leitner et al. published similar results [44]. O'Connell and Carrol's research proved that the use of bovine thrombin in the course of obtaining PRF may lead to the immediate degranulation of alpha granules and cause the release of all 
these growth factors [45], therefore leading to the very high concentration of growth factors at the beginning of the healing phase that quickly decrease after a few hours.

A large amount of full value, high-density bone is one of the conditions of aesthetic implant prosthetic reconstruction. The properly structured bone of a higher degree of mineralization is less susceptible to the resorption process; thus, it ensures a higher percentage of successes in implantological treatment. Moreover, it contributes to better long-term effects of the prosthetic treatment [46]. However, the bone will not be of good quality after the healing of the alveolus in each patient. Therefore, the physician's and patient's appropriate conduct before deciding on tooth extraction is important. It was proved that the mineral density of the osseous tissue reflects the biological activity of the bone; thus, attempts are being made to assess bone density using such a simple examination as CBCT [47]. Nevertheless, it is proven that $\mathrm{CBCT}$ equipment calibration and further conversion steps are needed to reliably assess the bone density in CBCT imaging [48]. Due to the fact that the imaging was performed at a remote facility, this was impossible, which constitutes a limitation of this study. Therefore, the result of the measurements needs to be referenced as GVs rather than Hounsfield units.

On the other hand, there are reports on the correlation between CBCT-derived bone GVs and the subjective tactile sensation of the perceived bone quality during implant placement. Abdulkarim et al. reported on the correlation between CBCT bone GVs and clinical bone quality, which was stronger in the absence of bone grafting material and weaker with graft, especially xenograft [49]. In our research, the grafting material was completely absorbable, so it was not affecting the measurements [50]. Moreover, numerous papers backing a correlation between CBCT-derived bone GVs and primary and secondary implant stability, which is a clinically significant parameter, were published [51-55]. Nevertheless, the literature data on those correlations are ambiguous, which has to be taken into consideration when drawing conclusions [50].

In this study, an attempt to assess the influence of PRF on newly formed bone was made. The authors' research demonstrated significant differences in the grayscale values of the newly formed bone after 6 months. Differences between the groups in favor of Group I (i.e., the group with PRF in the alveolus) were revealed. This might mean that the use of PRF may improve primary and secondary implant stability at the extraction site. The reason for this may be growth factors being active in the initial phase of healing which leads to the process of osseous bridges formation as well as faster callus formation and its mineralization. It is important for the acceleration of tissue healing that growth factors are present in the wound for a longer period. Thanks to the longer presence, their positive impact first on soft tissue healing and then bone healing is possible because the short-term influence of growth factors in the wound could not contribute to the acceleration and improvement of healing [43].

The accuracy of CBCT examination is good enough to use this method for the thorough analysis of the alveolar bone, and today's apparatuses make this examination involve very small doses of radiation. In this study, the width and height of the alveolar process were measured after tooth extraction and after 6 months, thereby making it possible to precisely examine the amount of bone. A statistically significant change in the width of the alveolar process was observed. It amounted, on average, to $0.87 \pm 0.4 \mathrm{~mm}$ in Group I with the use of PRF, that is the average loss amounted to $6.9 \%$ of the width of the bone, whereas in Group II without PRF, the average loss amounted to $1.18 \pm 1.1 \mathrm{~mm}$, i.e., $9.4 \%$. On the other hand, a statistically significant $(p=0.0148)$ change in the height of the alveolar process was also revealed within the space of 6 months of observation. In Group I with PRF, the change/loss amounted, on average, to $1.59 \pm 0.49 \mathrm{~mm}$ (i.e., the loss of $14.1 \%$ of the height), while in Group II without PRF, it amounted to $1.85 \pm 0.75 \mathrm{~mm}$, i.e., $21.5 \%$. It can be concluded that these results correlate with various previous scientific reports, and bone atrophy in the horizontal and transverse dimensions should be expected [1-5]. In light of the available literature, bone atrophy amounts, on average, to $25-30 \%$ after 6 months [1,2]. In this study, bone atrophy amounted to less than that of the abovementioned scientific reports, both in 
the study group and the control group. However, it is believed that this result was related to the atraumatic technique of tooth extraction together with covering the open alveolus with a flap, which had a significant influence on thrombus formation and its remodeling.

The research conducted revealed the possibility of preventing the atrophy of the alveolar process in the site of the extracted tooth through guided bone regeneration using entirely autologous material such as platelet-rich fibrin. The technique of securing plateletrich fibrin in the alveolus so that it was as atraumatic as possible for the patient requires further observation and elaboration.

\section{Conclusions}

Platelet-rich fibrin influences the reduction in the bone resorption process in the healing of the alveolus after tooth extraction. The use of platelet-rich fibrin also improves soft tissues healing and the healing of the post-extraction alveolus.

Author Contributions: Conceptualization, I.N. and D.C.; Data curation, D.C.; Investigation, D.C. and D.N.; Methodology, I.N., D.C., M.B. and D.N.; Validation, I.N.; Visualization, M.B.; Writing—original draft, I.N., D.C., M.B. and D.N.; Writing-review and editing, I.N. and M.B. All authors have read and agreed to the published version of the manuscript.

Funding: This research received no external funding.

Institutional Review Board Statement: The study was conducted in accordance with the Declaration of Helsinki and approved by the bioethics committee of the Medical University of Silesia (protocol: KNW/0022/KB1/97/II/10/11).

Informed Consent Statement: Informed consent was obtained from all subjects involved in the study.

Data Availability Statement: The data presented in this study are available on request from the corresponding author. The data are not publicly available due to containing sensitive information.

Conflicts of Interest: The authors declare no conflict of interest.

\section{References}

1. Araújo, M.G.; Lindhe, J. Dimensional Ridge Alterations Following Tooth Extraction. An Experimental Study in the Dog. J. Clin. Periodontol. 2005, 32, 212-218. [CrossRef] [PubMed]

2. Nevins, M.; Mellonig, J. Implant Therapy: Clinical Approaches and Evidence of Success; Quintessence Publishing Co. Inc.: Chicago, IL, USA, 1998; Volume 2, pp. 23-28.

3. Dominiak, M.; Łysiak, K. Odbudowa struktury kostnej w ubytkach poekstrakcyjnych-aspekty procesów fizjologicznych i regeneracyjnych po zastosowaniu biomateriałów-przegląd piśmiennictwa. Porad. Stomatol. 2004, 4, 5-12.

4. Ashman, A. Ridge Preservation: Important Buzzwords in Dentistry. Gen. Dent. 2000, 48, 304-312. [PubMed]

5. Lekovic, V.; Camargo, P.M.; Klokkevold, P.R.; Weinlaender, M.; Kenney, E.B.; Dimitrijevic, B.; Nedic, M. Preservation of Alveolar Bone in Extraction Sockets Using Bioabsorbable Membranes. J. Periodontol. 1998, 69, 1044-1049. [CrossRef] [PubMed]

6. Darby, I.; Chen, S.T.; Buser, D. Ridge Preservation Techniques for Implant Therapy. Int. J. Oral Maxillofac. Implant. 2009, 24 (Suppl.), 260-271.

7. Araújo, M.G.; Lindhe, J. Ridge Alterations Following Tooth Extraction with and without Flap Elevation: An Experimental Study in the Dog. Clin. Oral Implants Res. 2009, 20, 545-549. [CrossRef]

8. Simon, B.I.; Von Hagen, S.; Deasy, M.J.; Faldu, M.; Resnansky, D. Changes in Alveolar Bone Height and Width Following Ridge Augmentation Using Bone Graft and Membranes. J. Periodontol. 2000, 71, 1774-1791. [CrossRef]

9. Zubillaga, G.; Von Hagen, S.; Simon, B.I.; Deasy, M.J. Changes in Alveolar Bone Height and Width Following Post-Extraction Ridge Augmentation Using a Fixed Bioabsorbable Membrane and Demineralized Freeze-Dried Bone Osteoinductive Graft. J. Periodontol. 2003, 74, 965-975. [CrossRef]

10. Marciniak, J. Biomateriaty; Wydawnictwo Politechniki Śląskiej: Gliwice, Poland, 2002.

11. Choukroun, J.; Adda, F.; Schoeffler, C.; Vervelle, A. Une Opportunite' En Paro-Implantologie: Le PRF. Implantodontie 2001, 42 , e62.

12. Diss, A.; Dohan, D.M.; Mouhyi, J.; Mahler, P. Osteotome Sinus Floor Elevation Using Choukroun's Platelet-Rich Fibrin as Grafting Material: A 1-Year Prospective Pilot Study with Microthreaded Implants. Oral Surg. Oral Med. Oral Pathol. Oral Radiol. Endod. 2008, 105, 572-579. [CrossRef]

13. Dohan, D.M.; Choukroun, J.; Diss, A.; Dohan, S.L.; Dohan, A.J.J.; Mouhyi, J.; Gogly, B. Platelet-Rich Fibrin (PRF): A SecondGeneration Platelet Concentrate. Part II: Platelet-Related Biologic Features. Oral Surg. Oral Med. Oral Pathol. Oral Radiol. Endod. 2006, 101, e45-e50. [CrossRef] [PubMed] 
14. Dohan, D.M.; Choukroun, J.; Diss, A.; Dohan, S.L.; Dohan, A.J.J.; Mouhyi, J.; Gogly, B. Platelet-Rich Fibrin (PRF): A SecondGeneration Platelet Concentrate. Part III: Leucocyte Activation: A New Feature for Platelet Concentrates? Oral Surg. Oral Med. Oral Pathol. Oral Radiol. Endod. 2006, 101, e51-e55. [CrossRef] [PubMed]

15. Choukroun, J.; Diss, A.; Simonpieri, A.; Girard, M.-O.; Schoeffler, C.; Dohan, S.L.; Dohan, A.J.J.; Mouhyi, J.; Dohan, D.M. Platelet-Rich Fibrin (PRF): A Second-Generation Platelet Concentrate. Part IV: Clinical Effects on Tissue Healing. Oral Surg. Oral Med. Oral Pathol. Oral Radiol. Endod. 2006, 101, e56-e60. [CrossRef]

16. Choukroun, J.; Diss, A.; Simonpieri, A.; Girard, M.-O.; Schoeffler, C.; Dohan, S.L.; Dohan, A.J.J.; Mouhyi, J.; Dohan, D.M Platelet-Rich Fibrin (PRF): A Second-Generation Platelet Concentrate. Part V: Histologic Evaluations of PRF Effects on Bone Allograft Maturation in Sinus Lift. Oral Surg. Oral Med. Oral Pathol. Oral Radiol. Endod. 2006, 101, 299-303. [CrossRef]

17. Carroll, R.; Amoczky, S.; Graham, S.; O'Connell, S. Characterization of Autologous Growth Factors in Cascade Platelet Rich Fibrin Matrix (PRFM); Musculoskeletal Transplant Foundation: Edison, NJ, USA, 2005.

18. Dohan Ehrenfest, D.M.; Bielecki, T.; Jimbo, R.; Barbé, G.; Del Corso, M.; Inchingolo, F.; Sammartino, G. Do the Fibrin Architecture and Leukocyte Content Influence the Growth Factor Release of Platelet Concentrates? An Evidence-Based Answer Comparing a Pure Platelet-Rich Plasma (P-PRP) Gel and a Leukocyte- and Platelet-Rich Fibrin (L-PRF). Curr. Pharm. Biotechnol. 2012, 13, 1145-1152. [CrossRef] [PubMed]

19. Dohan, D.M.; Del Corso, M.; Charrier, J.-B. Cytotoxicity Analyses of Choukroun's Platelet-Rich Fibrin (PRF) on a Wide Range of Human Cells: The Answer to a Commercial Controversy. Oral Surg. Oral Med. Oral Pathol. Oral Radiol. Endod. 2007, 103, 587-593. [CrossRef]

20. Dohan, D.M.; Choukroun, J.; Diss, A.; Dohan, S.L.; Dohan, A.J.J.; Mouhyi, J.; Gogly, B. Platelet-Rich Fibrin (PRF): A SecondGeneration Platelet Concentrate. Part I: Technological Concepts and Evolution. Oral Surg. Oral Med. Oral Pathol. Oral Radiol. Endod. 2006, 101, e37-e44. [CrossRef]

21. Bilgen, F.; Ural, A.; Bekerecioglu, M. Platelet-Rich Fibrin: An Effective Chronic Wound Healing Accelerator. J. Tissue Viability 2021, 30, 616-620. [CrossRef]

22. Thorat, M.; Pradeep, A.R.; Pallavi, B. Clinical Effect of Autologous Platelet-Rich Fibrin in the Treatment of Intra-Bony Defects: A Controlled Clinical Trial. J. Clin. Periodontol. 2011, 38, 925-932. [CrossRef]

23. Sharma, A.; Pradeep, A.R. Treatment of 3-Wall Intrabony Defects in Patients with Chronic Periodontitis with Autologous Platelet-Rich Fibrin: A Randomized Controlled Clinical Trial. J. Periodontol. 2011, 82, 1705-1712. [CrossRef]

24. Heggendorn, F.L.; Heggendorn, C.; Vidal, F.; de Carvalho Silva, G.C.; Gonçalves, L.S.; de Oliveira Freitas Lione, V. LeukocytePlatelet Rich Fibrin on the Treatment of a Large Paradental Cyst: A Novel Regenerative Approach. Blood Coagul. Fibrinolysis 2021, 32, 411-417. [CrossRef] [PubMed]

25. Nagaraja, S.; Mathew, S.; Jain, N.; Jethani, B.; Nambiar, S.; Kumari, M.; Nair, S. Study of Antibacterial and Antifungal Efficacy of Platelet-Rich Fibrin and Platelet-Rich Fibrin Matrix. J. Conserv. Dent. 2019, 22, 415-419. [CrossRef] [PubMed]

26. Petrescu, B.N.; Mirica, I.C.; Miron, R.; Campian, R.S.; Lucaciu, O. Platelet Rich Fibrin as a Gingival Tissue Regeneration Enhancer. J. Dent. Sci. 2021, 16, 536-539. [CrossRef] [PubMed]

27. Kempraj, J.; Sundaram, S.S.; Doss, G.P.T.; Nakeeran, K.P.; Raja, V.B.K.K. Maxillary Sinus Augmentation Using Xenograft and Choukroun's Platelet-Rich Fibrin as Grafting Material: A Radiological Study. J. Maxillofac. Oral Surg. 2020, 19, 263-268. [CrossRef]

28. Sunitha Raja, V.; Munirathnam Naidu, E. Platelet-Rich Fibrin: Evolution of a Second-Generation Platelet Concentrate. Indian J. Dent. Res. 2008, 19, 42-46. [CrossRef]

29. Barone, A.; Aldini, N.N.; Fini, M.; Giardino, R.; Calvo Guirado, J.L.; Covani, U. Xenograft versus Extraction Alone for Ridge Preservation after Tooth Removal: A Clinical and Histomorphometric Study. J. Periodontol. 2008, 79, 1370-1377. [CrossRef]

30. Iasella, J.M.; Greenwell, H.; Miller, R.L.; Hill, M.; Drisko, C.; Bohra, A.A.; Scheetz, J.P. Ridge Preservation with Freeze-Dried Bone Allograft and a Collagen Membrane Compared to Extraction Alone for Implant Site Development: A Clinical and Histologic Study in Humans. J. Periodontol. 2003, 74, 990-999. [CrossRef]

31. Crespi, R.; Capparè, P.; Gherlone, E. Dental Implants Placed in Extraction Sites Grafted with Different Bone Substitutes: Radiographic Evaluation at 24 Months. J. Periodontol. 2009, 80, 1616-1621. [CrossRef]

32. Nevins, M.; Mellonig, J.T.; Clem, D.S.; Reiser, G.M.; Buser, D.A. Implants in Regenerated Bone: Long-Term Survival. Int. J. Periodontics Restor. Dent. 1998, 18, 34-45.

33. Sclar, A.G. The Bio-Col Technique. In Soft Tissue and Esthetic Considerations in Implant Therapy; Quintessence Publishing Co. Inc.: Chicago, IL, USA, 2003; pp. 75-112.

34. Lekovic, V.; Kenney, E.B.; Weinlaender, M.; Han, T.; Klokkevold, P.; Nedic, M.; Orsini, M. A Bone Regenerative Approach to Alveolar Ridge Maintenance Following Tooth Extraction. Report of 10 Cases. J. Periodontol. 1997, 68, 563-570. [CrossRef]

35. Brownfield, L.A.; Weltman, R.L. Ridge Preservation with or without an Osteoinductive Allograft: A Clinical, Radiographic, Micro-Computed Tomography, and Histologic Study Evaluating Dimensional Changes and New Bone Formation of the Alveolar Ridge. J. Periodontol. 2012, 83, 581-589. [CrossRef] [PubMed]

36. Trisi, P.; Rebaudi, A.; Calvari, F.; Lazzara, R.J. Sinus Graft with Biogran, Autogenous Bone, and PRP: A Report of Three Cases with Histology and Micro-CT. Int. J. Periodontics Restor. Dent. 2006, 26, 113-125.

37. Marsell, R.; Einhorn, T.A. The biology of fracture healing. Injury 2011, 42, 551-555. [CrossRef] [PubMed]

38. Dohan Ehrenfest, D.M.; Rasmusson, L.; Albrektsson, T. Classification of Platelet Concentrates: From Pure Platelet-Rich Plasma (P-PRP) to Leucocyte- and Platelet-Rich Fibrin (L-PRF). Trends Biotechnol. 2009, 27, 158-167. [CrossRef] [PubMed] 
39. Dohan Ehrenfest, D.M.; Del Corso, M.; Diss, A.; Mouhyi, J.; Charrier, J.-B. Three-Dimensional Architecture and Cell Composition of a Choukroun's Platelet-Rich Fibrin Clot and Membrane. J. Periodontol. 2010, 81, 546-555. [CrossRef]

40. El-Sharkawy, H.; Kantarci, A.; Deady, J.; Hasturk, H.; Liu, H.; Alshahat, M.; Van Dyke, T.E. Platelet-Rich Plasma: Growth Factors and pro- and Anti-Inflammatory Properties. J. Periodontol. 2007, 78, 661-669. [CrossRef] [PubMed]

41. Werther, K.; Christensen, I.J.; Nielsen, H.J. Determination of Vascular Endothelial Growth Factor (VEGF) in Circulating Blood: Significance of VEGF in Various Leucocytes and Platelets. Scand. J. Clin. Lab. Investig. 2002, 62, 343-350. [CrossRef] [PubMed]

42. Becker, W.; Dahlin, C.; Becker, B.E.; Lekholm, U.; van Steenberghe, D.; Higuchi, K.; Kultje, C. The Use of E-PTFE Barrier Membranes for Bone Promotion around Titanium Implants Placed into Extraction Sockets: A Prospective Multicenter Study. Int. J. Oral Maxillofac. Implant. 1994, 9, 31-40.

43. Dohan Ehrenfest, D.M.; Doglioli, P.; de Peppo, G.M.; Del Corso, M.; Charrier, J.-B. Choukroun's Platelet-Rich Fibrin (PRF) Stimulates in Vitro Proliferation and Differentiation of Human Oral Bone Mesenchymal Stem Cell in a Dose-Dependent Way. Arch. Oral Biol. 2010, 55, 185-194. [CrossRef]

44. Leitner, G.C.; Gruber, R.; Neumüller, J.; Wagner, A.; Kloimstein, P.; Höcker, P.; Körmöczi, G.F.; Buchta, C. Platelet Content and Growth Factor Release in Platelet-Rich Plasma: A Comparison of Four Different Systems. Vox Sang. 2006, 91, 135-139. [CrossRef]

45. O'Connell, S.; Carroll, R.; Beavis, A.; Arnoczky, S.P. Flow Cytometric Characterization of Cascade Platelet-Rich Fibrin Matrix (PRFM); The Impact of Exogenous Thrombin on Platelet Concentrates (PC); Musculoskeletal Transplant Foundation: Edison, NJ, USA, 2006; Volume 4, p. 66.

46. Taylor, T.; Gans, S.; Jones, E.; Firestone, A.; Johnston, W.; Kim, D.-G. Comparison of Micro-CT and Cone Beam CT-Based Assessments for Relative Difference of Grey Level Distribution in a Human Mandible. Dentomaxillofac. Radiol. 2013, 42, 25117764. [CrossRef] [PubMed]

47. Kim, D.-G. Can Dental Cone Beam Computed Tomography Assess Bone Mineral Density? J. Bone Metab. 2014, 21, 117-126. [CrossRef] [PubMed]

48. Eguren, M.; Holguin, A.; Diaz, K.; Vidalon, J.; Linan, C.; Pacheco-Pereira, C.; Lagravere Vich, M.O. Can Gray Values Be Converted to Hounsfield Units? A Systematic Review. Dentomaxillofac. Radiol. 2022, 51, 20210140. [CrossRef] [PubMed]

49. Abdulkarim, H.H.; Zeng, R.; Pazdernik, V.K.; Davis, J.M. Effect of Bone Graft on the Correlation between Clinical Bone Quality and CBCT-Determined Bone Density: A Pilot Study. J. Contemp. Dent. Pract. 2021, 22, 756-762. [CrossRef]

50. Schnutenhaus, S.; Götz, W.; Dreyhaupt, J.; Rudolph, H.; Luthardt, R.G.; Edelmann, C. Associations among Primary Stability, Histomorphometric Findings, and Bone Density: A Prospective Randomized Study after Alveolar Ridge Preservation with a Collagen Cone. Dent. J. 2020, 8, 112. [CrossRef] [PubMed]

51. Ivanova, V.; Chenchev, I.; Zlatev, S.; Mijiritsky, E. Correlation between Primary, Secondary Stability, Bone Density, Percentage of Vital Bone Formation and Implant Size. Int. J. Environ. Res. Public Health 2021, 18, 6994. [CrossRef]

52. Al-Jamal, M.F.J.; Al-Jumaily, H.A. Can the Bone Density Estimated by CBCT Predict the Primary Stability of Dental Implants? A New Measurement Protocol. J. Craniofac. Surg. 2021, 32, e171-e174. [CrossRef]

53. Isoda, K.; Ayukawa, Y.; Tsukiyama, Y.; Sogo, M.; Matsushita, Y.; Koyano, K. Relationship between the Bone Density Estimated by Cone-Beam Computed Tomography and the Primary Stability of Dental Implants. Clin. Oral Implants Res. 2012, 23, 832-836. [CrossRef]

54. Salimov, F.; Tatli, U.; Kürkçü, M.; Akoğlan, M.; Oztunç, H.; Kurtoğlu, C. Evaluation of Relationship between Preoperative Bone Density Values Derived from Cone Beam Computed Tomography and Implant Stability Parameters: A Clinical Study. Clin. Oral Implants Res. 2014, 25, 1016-1021. [CrossRef]

55. Wada, M.; Suganami, T.; Sogo, M.; Maeda, Y. Can We Predict the Insertion Torque Using the Bone Density around the Implant? Int. J. Oral Maxillofac. Surg. 2016, 45, 221-225. [CrossRef] 